\title{
El discurso falso en los personajes femeninos de la novela griega
}

\author{
Elena REDONDO MOYANO \\ Universidad del País Vasco/Euskal Herriko Unibertsitatea \\ elena.redondo@ehu.es
}

RESUMEN: En este trabajo se analiza el uso que los personajes femeninos de las novelas griegas hacen del discurso falso. Tomando como punto de partida el análisis del discurso femenino en la tragedia ática, uno de los géneros literarios que más influyó en los discursos novelísticos, se estudia qué personajes de la novela utilizan el discurso falso y la finalidad con que lo hacen. Se descubren dos tipos de discursos falsos: los defensivos, usados por las protagonistas femeninas o por personajes secundarios similares a ellas en clase social e ideología, y los ofensivos, usados por personajes secundarios de clase social inferior y moralmente reprochables dentro del ideario amoroso que la novela publicita.

\section{False Speech in the Female Characters in the Greek Novel}

ABSTRACT: This paper examines how the female characters in Greek novels have recourse to false speech. Based on an analysis of female speech in Attic tragedy, which was one of the literary genres that exerted the greatest influence on speech parts of the novels, a study is conducted to find out which characters in the novel employ false speech and their purpose in doing so. Two types of false speech were identified: the defensive one, used by the female protagonists or by secondary characters of similar social and ideological status, and the offensive one, used by characters of lower rank, and blameworthy morality within the ideological love's framework publicized through the novel.

PAlabRas ClaVE: Novela griega, discurso femenino, discurso falso, Caritón, Jenofonte de Éfeso, Aquiles Tacio, Heliodoro, tragedia griega, retórica.

KEYWORDS: Greek novel, female speech, false speech, Chariton, Xenophon of Ephesus,

Achilles Tatius, Heliodorus of Emesa, Greek tragedy, rhetoric.

FECHA DE RECEPCIÓN: 23 de agosto de 2011.

FECHA DE ACEPTACIÓN: 25 de marzo de 2012. 



\title{
El discurso falso en los personajes femeninos de la novela griega ${ }^{1}$
}

\author{
Elena REDONDO MOYANO
}

Las novelas griegas llamadas "de amor o aventuras" fueron compuestas entre los siglos I-IV ${ }^{2}$ por autores que escribían en griego en ciudades de la parte oriental del Imperio romano. Durante esos siglos, las élites de esas ciudades ${ }^{3}$ promovieron un movimiento cultural inspirado en modelos del pasado, principalmente en las obras producidas en la Atenas del s. v a. C. ${ }^{4}$ Recrearon así su propia imagen de ese pasado y construyeron una paideía

\footnotetext{
${ }^{1}$ Este trabajo ha sido realizado dentro del Grupo de Investigación “Tradiciones Clásicas" (GIU07-26) y de su continuación "Litterarum" (GIU10-19). Una primera versión del mismo fue presentada en el marco del III Coloquio Internacional de Retórica que se desarrolló los días 14 y 15 de abril de 2011 organizado por la UNAM. Doy las gracias por las sugerencias que se me hicieron, especialmente a los doctores Barbara Cassin y David García.

${ }^{2}$ Citamos aquí la fecha que aparece en la bibliografía reciente: la obra de Caritón ha sido datada en el s. I: cf. Bowie, 2002; Reardon, 2003; Ruiz Montero, 2006. La de Longo se sitúa entre la segunda mitad del s. II y la primera del s. III: cf. Hunter, 2003; Ruiz Montero, 2006. La de Aquiles Tacio fue escrita en la segunda mitad o en el último cuarto del s. II: cf. Plepelits, 2003 y Ruiz Montero, 2006. La de Heliodoro fue compuesta en los ss. III o IV: cf. la discusión en Bowie, 2008. La fecha de la novela de Jenofonte de Éfeso sigue siendo objeto de discusión: mientras que O' Sullivan, 1995, defiende que fue compuesta antes que la de Caritón, y, por tanto, antes del s. I, la opinión más generalizada entre los estudiosos la sitúa después de esa primera novela, en el s. II: cf. Kytzler, 2003 y Ruiz Montero, 2006.
}

${ }^{3}$ En Whitmarsh, 2008, se analiza la relación entre las novelas (griegas y latinas) y las élites de las ciudades del Imperio. Aunque la opinión más generalizada (cf. Ruiz Montero, 2006 y, sobre todo, Lalanne, 2006) es que existe una estrecha relación entre ellas, Whitmarsh puntualiza que la novela no puede considerarse "literatura de élite" en el mismo nivel que la oratoria de la misma época, dado que en la novela se dibuja un marco social amplio en el que tienen cabida todas las clases sociales y en el que ocasionalmente se cuestionan las relaciones de poder y la estructura de la sociedad de la época.

${ }^{4}$ En Cribiore, 1996 y 2001, se puede ver un análisis del uso que se hizo de la poesía y de la prosa clásica en la época imperial en todos los niveles de la educación. 
griega, un ideal de vida, cultura y valores ${ }^{5}$ que fue llamado dentro del ámbito retórico "Segunda Sofística" (Filóstrato, s. III), un nombre que ponía de manifiesto su relación con el glorioso pasado clásico en el que vivieron los primeros sofistas. Debido a este movimiento y al absoluto predominio que la retórica detentaba en la educación, el panorama literario de la época ${ }^{6}$ se caracteriza por la prevalencia de la imitatio, ${ }^{7}$ una pauta artística según la cual la buena práctica literaria debía partir de las grandes obras del pasado, que se consideraban modelos a imitar por su gran calidad literaria. Como muchas de esas obras estaban escritas en ático, la literatura de la época, y dentro de ella la novela, está escrita en un ático que imita al que utilizaron los escritores clásicos atenienses de los siglos v y IV a. C. ${ }^{8}$

Como consecuencia de esta poética, en la novela son apreciables las influencias de diversos géneros literarios anteriores, ${ }^{9}$ entre las cuales debemos destacar respecto al tema de este trabajo el drama ático de la época clásica. ${ }^{10}$ Efectivamente, entre los autores más leídos en las escuelas de retórica se encuentran, además de Homero, los trágicos: los papiros de la época muestran que al público cultivado le gustaba más Eurípides que Esquilo o Sófocles. Eurípides tenía la ventaja de presentar un griego accesible y de que muchas de sus obras tenían un carácter muy retórico, de manera que procuraban al lector una educación que respondía a las exigencias estéticas de la época. Otro autor muy leído fue Menandro, ${ }^{11}$ quien gozó de gran fama no solo porque su griego era también accesible, sino porque representaba la vida corriente, con personajes estereotipados, pero no pertenecientes ya al mito, como los de la tragedia.

${ }^{5}$ Cf. Lalanne, 2006, pp. 35-37.

${ }^{6}$ Para una visión de conjunto de la producción literaria de la época, cf. Bowie, 2008, pp. 17-38.

${ }^{7}$ Cf. Reardon, 1971, p. 7.

${ }^{8}$ De entre las obras escritas en prosa ática, se leían sobre todo las de los historiadores Tucídides y Jenofonte, las del filósofo Platón y las del orador Demóstenes, todos ellos considerados modelos del uso del dialecto ático y de estilo: cf. Whitmarsh, 2008, p. 7. Entre los recientes estudios del uso del aticismo cabe citar Kazazis, 2007 y Caragounis, 2010.

${ }^{9}$ Cf. Ruiz Montero, 2006, p. 43 ss: la tradición utópica, la tradición historiográfica, la tradición dramática, la tradición épica, la elegía alejandrina y las leyendas locales.

${ }^{10}$ Cf. Crismani, 1997, passim; Cribiori, 2001, pp. 197-201; Ruiz Montero, 2003, pp. 48-54 y Marincic, 2007, 1, pp. 68-200.

${ }^{11}$ Blanchard, 1997. 
La influencia del teatro se debió también presumiblemente al hecho de que las novelas, obras narrativas, cuentan, no obstante, con un importante componente de estilo directo. Efectivamente, los diálogos entre personajes constituyen un 44\% de la novela de Caritón, un $29 \%$ en la de Jenofonte, un $24 \%$ en la de Longo, un tercio del total de la novela de Heliodoro y un porcentaje todavía mayor en la de Aquiles Tacio, cuya narración está construida en gran parte en primera persona. ${ }^{12}$ Gracias a los Progymnásmata - manuales en los que se recoge la teoría básica para la composición oral y escrita que los gramáticos y rétores usaban en la fase de la enseñanza primaria y secundaria - sabemos que en las escuelas de retórica el estilo directo se trabajaba por medio de la "prosopopeya" o "etopeya", ${ }^{13}$ un ejercicio en el que se pedía al estudiante que asumiera el papel de algún personaje mítico o literario conocido, situado en una situación determinada de su trayectoria vital, y que reprodujera las palabras que tal personaje pronunciaría para la ocasión. Entre los modelos más útiles que los estudiantes podían imitar para este ejercicio se encontraban, sin duda, las obras dramáticas, que estaban compuestas fundamentalmente de diálogos, y en las que aparecían, además, monólogos y cartas, formas compositivas que se encuentran también en las novelas. ${ }^{14}$

Los diálogos de la novela pertenecen en mayor medida a personajes masculinos que a personajes femeninos, porque estas obras sitúan su acción dramática en el mundo griego de la época clásica (Caritón y Heliodoro) o en una época indefinida que lo recuerda (Jenofonte de Éfeso, Longo y Aquiles Tacio), y en ese período histórico existía una clara división de los espacios en relación con el género: el espacio público era ocupado por los varones, mientras que el lugar reservado a las mujeres era el ô̂kos, la casa familiar, el ámbito privado. ${ }^{15}$ Las apariciones públicas de las mujeres se limitaban, por tanto, como se aprecia bien en la novela, a la asistencia a determinados actos rituales frecuentemente de carácter religioso. ${ }^{16}$ Sin embargo, el género

${ }^{12}$ Ruiz Montero, 2006, p. 43.

${ }^{13}$ Para este ejercicio, cf. Teón, 115.11 (Spengel), Hermógenes, 20.7-8 (Rabe), Aftonio, 34.2-3 (Rabe) y Nicolao, 63 (Felten); las traducciones de estas obras se pueden encontrar en Reche Martínez, 1991, y Redondo Moyano, $2007 \mathrm{~b}$.

${ }^{14}$ Cribiorie, pp. 228-229.

${ }^{15}$ Cf. Picazo Gurina, 2008, pp. 86-89, para los espacios que ocupaban las mujeres, y McClure, 1999, pp. 19-24, 28-29 y 264 para su exclusión de la vida pública.

${ }^{16}$ Cf. Caritón, 1, 1, 4 y Jenofonte de Éfeso, 1, 2, 2. 
novelístico incorpora el motivo del viaje, ${ }^{17}$ un procedimiento literario mediante el cual la pareja de protagonistas se ve alejada de su ciudad de origen y de los privilegios que en ella disfruta, de manera que debe enfrentarse a diversas situaciones penosas, las pruebas, en las cuales se manifiestan el amor mutuo y la fidelidad que constituye el ideario amoroso que se publicita en las novelas. ${ }^{18}$ Debido a la existencia en las tramas novelísticas del viaje, las protagonistas ocupan espacios diferentes de los habituales para las mujeres griegas de la época clásica, ${ }^{19}$ reflejándose así una concepción propia de la época en la que las novelas fueron compuestas y ligada a la dominación romana. Efectivamente, la idea romana sobre la presencia de la mujer en los espacios públicos no era tan restrictiva como la griega y permitía una mayor participación pública de las mujeres (en viajes o ceremonias varias), especialmente de las de clase alta, a las cuales era habitual ver en público acompañando a sus maridos, como una manifestación más del poder que ellos detentaban. ${ }^{20}$ Esta mayor presencia femenina en distintos ambientes, así como la relevancia general de los personajes femeninos de las novelas, obligaba a los novelistas a otorgarles un papel importante en la trama y en los discursos directos que la recorrían. El drama ático suponía, también en este aspecto, un modelo imprescindible, ya que en él diversas figuras femeninas del mito jugaban, gracias a las palabras que pronunciaban, un papel preponderante en la trama.

${ }^{17}$ El desplazamiento espacial se encuentra en todas las novelas salvo en la de Longo, que se sitúa en un ambiente bucólico (cf. la obra de Teócrito, del s. III a. C.), en el cual los viajes no eran posibles.

${ }^{18}$ Estas pruebas que los jóvenes enamorados deben de superar antes de ser incluidos en la clase de los adultos casados han sido interpretadas como ritos de pasaje asociados al género y a la clase social por García Gual, 1992, y Lalanne, 2006. Sobre la novedad que suponen el paralelismo en la edad, en la clase social y en el amor mutuo y fiel que se encuentra entre los protagonistas de la novela (frente a las convenciones eróticas habituales según las cuales los dos miembros de la pareja solían tener edades diferentes y tenían adjudicados roles claramente desiguales, cf. Winkler 1989, 117 y Konstan, 1994 passim), Ruiz Montero, 2006, 30 ss., recoge testimonios que muestran que este ideario amoroso se encuentra también en otro tipo de textos (Plutarco y Musonio Rufo) y en otras manifestaciones culturales de la época (epitafios, iconografía funeraria, monedas). Sobre la dimensión socio-política que este ideario tenía entre las clases elevadas de las ciudades orientales, cf. Imbert, 1992, y, particularmente, Lalanne, 2006, especialmente en pp. 30-31.

${ }^{19}$ Cf. Redondo Moyano, 2011, en prensa.

${ }^{20}$ Cf. Hallett y Skinner, 1997, pp. 8-9. 
Las características del discurso femenino en la producción dramática han sido bien establecidas en monografías como la de Laura McClure. ${ }^{21}$ Como es lógico esperar en una sociedad en la que los espacios públicos estaban vetados a las mujeres, de ellas se esperaba, en primer lugar, que se mantuvieran en silencio. ${ }^{22}$ No obstante, cuando la trama obligaba a darles voz, su discurso normativo era el lamento, ${ }^{23}$ un tipo de expresión que ha sido estudiado en la novela,${ }^{24}$ donde aparece en forma de diálogos, y, sobre todo, en los monólogos. Pero también se considera propio de las protagonistas dramáticas el discurso descontrolado y carente de fiabilidad, es decir, el discurso falso. ${ }^{25} \mathrm{Y}$ es en esta última característica del discurso femenino en la que vamos a centrar nuestra atención, estudiándola para el corpus de la novela.

\section{El discurso falso}

En la tradición literaria, ${ }^{26}$ la relación entre mujer y discurso falso tiene su origen en Pandora, la primera mujer griega, que fue dibujada por Hesíodo como falsa y astuta: efectivamente, entre los dones que se le concedieron se citan su habilidad para urdir mentiras y para expresarlas con palabras seductoras. ${ }^{27}$ Entre las primeras manifestaciones literarias del tópico cabe citar a la Helena homérica, a quien Menelao atribuye la capacidad de imitar las voces de las esposas de los argivos encerrados

${ }^{21}$ Cf. MacClure, 1999, donde se estudia la producción dramática clásica desde el punto de vista de la diferencia entre el discurso propio de varones y el propio de mujeres. En esta obra se puede encontrar también una amplia bibliografía para profundizar en este aspecto.

${ }^{22}$ El silencio era un ornato tradicional en las mujeres; cf. McClure, 1999, pp. 19-24, 34-35, 71-72 y 93-94 y Foley, 2001, pp. 91, 111, 115 y 210. Para un estudio del silencio en la novela griega, cf. Futre Pinheiro, 2001.

${ }^{23}$ Cf. MacClure 1999, pp. 40-47, 70-72, 95-96, 102-103 y 156-157; Foley, 2001, pp. 21-55.

${ }^{24}$ Cf. Ruiz Montero, 1988, pp. 82 y 152, y la conferencia "Mujeres desesperadas: tipología de la 'enamorada asesina' en la novela griega”, impartida en el XIV Congreso Internacional de Teatro Clásico Grecolatino y su Pervivencia en la Cultura Occidental (Valencia, 7-8 de octubre de 2010), que aparecerá publicada en las actas correspondientes.

${ }^{25}$ Cf. McClure, 1999, p. 24 ss., 74-76 y 103 y Foley, 2001, p. 207.

${ }^{26}$ Cf. McClure, 1999, p. 26 y n. 96; West, 1987, p. 260 y Cropp, 2000, p. 253.

${ }^{27}$ Hes., Op., $78-80$ y 375. 
en el caballo de madera, ${ }^{28}$ y llamarlos por su nombre con la intención de descubrirlos. Dado que Helena utiliza su facilidad discursiva en contra de los argivos y a favor de los troyanos, su capacidad es vista como una clara característica negativa del personaje. Por otro lado, el Agamenón de la Odisea $^{29}$ proclama desde el Hades la desconfianza que le merece el género femenino por el que ha sido engañado y asesinado. En la poesía lírica, en el misógino Yambo de las mujeres de Semónides, ${ }^{30}$ la producción de discursos falsos se asocia al humor cambiante de las féminas que lo saben todo, como la perversa zorra.

Que las mujeres mentían cuando hablaban era una creencia común, ${ }^{31}$ que encuentra su expresión en formas diversas entre los tragediógrafos. ${ }^{32}$ Así, fue muy conocido un verso de Sófocles conservado en forma de fragmento, "yo escribo los juramentos de las mujeres en agua", ${ }^{33}$ que tuvo la fortuna de ser reutilizado y reelaborado por epigramatistas y autores latinos de poesía amorosa, como Catulo, ${ }^{34}$ Propercio $^{35}$ u Ovidio. ${ }^{36}$ El mismo Sófocles hizo muy popular a Pandora durante la época clásica, gracias al drama satírico que compuso sobre este personaje. Pero es en la obra de Eurípides donde se encuentran con más frecuencia testimonios de la falsedad del discurso femenino o de la falta de credibilidad de las mujeres. ${ }^{37}$

${ }^{28}$ Od., 11, 277 ss.

${ }^{29}$ Od., 11, 427-34; 11, 456 ss.

${ }^{30}$ Cf. vv. 7-11 (West).

${ }^{31}$ Es significativo al respecto que Aristóteles considere que la falsedad es una característica propia del sexo femenino, al que describe como "aficionado a las chanzas ( $p h i$ loloídoron), carente de vergüenza (anaidésteron) y mentiroso (pseudésteron)", cf. Hist. An., 608b3-609b18.

32 En la comedia, los testimonios de esta creencia son menos frecuentes: cf. Antiph., 251 y Men., 584-5 y 591. El testimonio de Stob., 4, 22, 7 (sección en la que se condena a las mujeres por su capacidad de manipular mediante el uso de la palabra) demuestra la pervivencia del tópico a lo largo de los siglos.

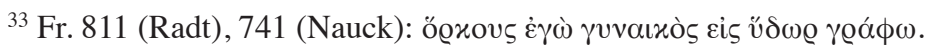

${ }^{34}$ Catul., 70.

${ }^{35}$ Prop., 2, 28, 7-8.

${ }^{36}$ Ov., Am., 2, 16, 45-56.

${ }^{37}$ Cf. Hipp., 480-81 y 638-50; Or., 1103; IT, 1298; Med., 408-9 y 421 ss. y los fragmentos 440, 463, 464, 671 (Nauck). 
Además de estos testimonios, en la tragedia hay impresionantes ejemplos de discursos femeninos falsos, como los de Hécuba, ${ }^{38}$ Clitemnestra $^{39}$ o Medea. ${ }^{40}$ Todos ellos tienen en común dos características: por un lado, buscan venganza, como respuesta a las ofensas padecidas; por otro, resultan fatales para sus destinatarios. Solo el falso discurso de la Helena de Eurípides,$^{41}$ cuando, tras el reconocimiento de Menelao, decide que hay que recurrir a la astucia y diseña un plan para la salvación de ambos, no resulta nocivo para su destinatario (Teoclímeno) y es solo un instrumento de salvación para ella y su esposo.

En las novelas aparece también el discurso femenino falso, pero su distribución es muy desigual: puesto en boca de personajes protagonistas, se encuentra solo en dos novelas, la de Caritón y la de Heliodoro, obras que, aunque alejadas en el tiempo de su composición, tienen en común dos características, el situar la acción en la época clásica y el tener ambas como protagonistas a mujeres de la más alta alcurnia.

La novela de Caritón tiene como protagonista femenina a Calírroe, la hija del estratego Hermógenes, el personaje histórico citado por Tucídides como vencedor de los atenienses en la batalla de Siracusa, el cual es dibujado en la novela como el ciudadano más poderoso de su ciudad. Calírroe se sirve del engaño y del discurso falso en tres ocasiones, todas ellas en el ámbito del viaje, motivo literario que proporcionaba, desde la Odisea, el marco extraordinario en el que se desarrollaba la experiencia vital de los personajes excepcionales, de los héroes ${ }^{42} \mathrm{y}$, en el caso de las novelas, también de las heroínas.

El primer destinatario de un discurso falso es Terón, el jefe de la banda de piratas que ha raptado a Calírroe de la rica tumba en la que su familia la había enterrado $(1,6,1)$ tras darla por muerta $(1,4,12)$. Terón trata continuamente de engañar a la joven en cuanto a sus intenciones, prometiéndole que la devolverá a su familia, aunque su único objetivo es quedarse

${ }^{38}$ E., Hec., 968 ss., cuando engaña a Poliméstor, el asesino de su hijo Polidoro, para atraerlo hacia las tiendas de las esclavas y cegarlo.

${ }^{39}$ A., 587 ss., cuando Clitemnestra recibe amistosamente a Agamenón que regresa de Troya.

${ }^{40}$ E., Med., 869 ss., cuando finge ante Jasón aceptar su boda y que se dispone a enviar un regalo a su prometida.

${ }^{41}$ E., Hel., 813 ss.

${ }^{42}$ Futre, 1994, p. 321 y 322. 
con su rico ajuar funerario y venderla como esclava en un lugar alejado, como una parte más del botín. La muchacha es perfectamente consciente de lo que sucede, pero, temerosa ante la situación en que se encuentra $(1,11,1)$, sigue el juego de Terón, que interpreta su fingida aquiescencia como estupidez $(1,13,10)$ y mantiene su farsa hasta que se despide de ella, tras venderla como esclava en una finca jonia a la que arriba con su nave. Le asegura, entonces, que vientos contrarios le impiden cumplir su palabra de devolverla a Siracusa y, dado que debe partir para un largo viaje, cuyas molestias desea ahorrarle, la va a dejar entre amigos (en realidad sus nuevos amos), para recogerla a la vuelta; le anima, además, a quedarse con los objetos del ajuar funerario que desee, una invitación absurda, ya que todos ellos eran propiedad de la familia de la muchacha y de ella misma. La respuesta de Calírroe es la siguiente:43 "Te estoy agradecida, padre, por tu bondad hacia mí. ¡Ojalá os devuelvan a todos vosotros los dioses la justa recompensa! Yo considero de mal agüero usar ofrendas funerarias. Guardádmelo bien todo. A mí me basta con este anillito que llevaba incluso muerta". ${ }^{44}$ La habilidad en el manejo del discurso queda patente en estas palabras, que son portadoras de un doble mensaje, uno superficial y adecuado a la situación, otro oculto, en el que expresa su verdadera opinión, sin poner por ello en riesgo su persona. Efectivamente, por un lado, mantiene el engaño de Terón, al agradecerle los favores que supuestamente le ha hecho, al llamarle páter, término usual en el trato cariñoso con las personas mayores, y al expresar, como solía ser habitual en las despedidas, un deseo de felicidad para el que parte. Sin embargo, sus palabras están cargadas de ironía, ya que, sabiendo que no ha recibido de él más que males y que no la ha tratado como un padre, sino como un pirata, el deseo que solicita de los dioses no es otro que la muerte de Terón, que sería la justa recompensa por los delitos de secuestro, robo de una tumba y venta de una mujer libre que él y los piratas de su banda habían cometido. Por otro, renuncia, aparentemente de forma voluntaria, a lo que sabe son objetos de su propiedad, y sigue la farsa de Terón al pedirle que se los guarde para el momento de su supuesto regreso, porque en realidad sabe que los piratas de ninguna manera le

${ }^{43}$ Las traducciones de Caritón las tomamos de J. Mendoza, 1979.

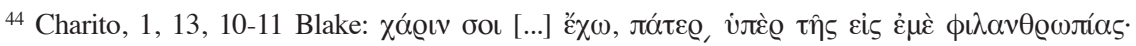

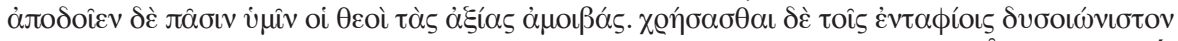

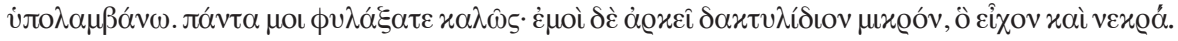


permitirían conservarlos. Sin embargo, les recuerda que es de mal agüero para los vivos el uso de ofrendas destinadas a los muertos, anticipando, de este modo, el funesto destino que les aguarda en su próximo viaje. Por medio de sus palabras, Calírroe queda caracterizada como una mujer astuta, con gran capacidad de adaptación a las nuevas circunstancias y muy hábil en manejo de la palabra, de la que se sirve como un medio para salvaguardar su seguridad.

El segundo destinatario de un discurso falso de la heroína de la novela de Caritón es Dionisio, el señor más importante de Mileto, que resulta ser el amo al que ha sido vendida. Calírroe le es presentada, siguiendo la versión dada por Terón, como una esclava sibarita a la que su ama vendió por los celos que su hermosura le provocaban $(2,3,7)$. El mismo Dionisio, conquistado por su belleza, que le parece impropia de su condición servil, ${ }^{45}$ le dispensa un trato magnánimo y le anima a contar su historia sin ocultar la verdad $(2,5,3,6)$, tratándola, por tanto, como huésped y no como esclava. Ella le cuenta esta versión:

Soy hija de Hermócrates, el estratego de Siracusa. Habiéndome quedado sin voz por un repentino golpe me enterraron mis padres con todo lujo. Unos ladrones de tumbas abrieron el sepulcro; me encontraron a mí ya volviendo a respirar, me condujeron aquí, y Terón me entregó a Leonas ${ }^{46}$ en un lugar solitario. ${ }^{47}$

Calírroe combina en estas palabras hechos verdaderos (su linaje, su entierro, su rapto) con importantes omisiones, como su matrimonio y la causa por la que ha recibido el golpe que la hizo parecer muerta, de manera que logra que Dionisio se haga de ella una idea parcialmente falsa, la de una muchacha soltera, de alta alcurnia, que ha sufrido terribles avatares. Esta imagen es la que ha calculado que le conviene más en su situación, ya que, si hubiera contado que estaba casada y que había sido objeto de violencia por parte de su marido, le habría sido imposible no

${ }^{45}$ Sobre la concepción de la belleza física y su significado en la novela, cf. Redondo Moyano, 2007a.

${ }^{46}$ Leonas es el administrador de la finca de Dionisio: es el personaje con el que Terón conecta tras su llegada a Jonia y con el que tramita la venta de Calírroe.

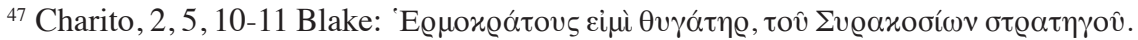

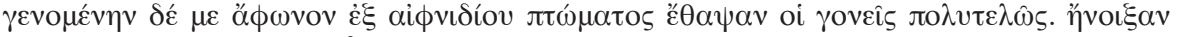

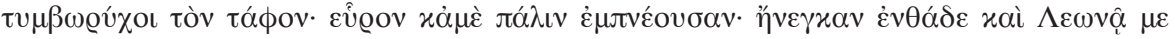

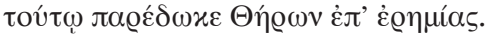


explicar también que la causa de esta violencia era una supuesta infidelidad suya, que no estaba en situación de $\operatorname{refutar}^{48}$ y que seguramente minaría su credibilidad, privándola de lo que buscaba conseguir de Dionisio:

Te suplico, Dionisio (pues eres griego y participas de una ciudad humanitaria y de educación), que no seas igual a los violadores de tumbas y no me prives de mi patria y mis parientes. Poco es para ti, que eres rico, un solo esclavo, y no perderás mi precio si me devuelves a mi padre. Pues Hermócrates no es desagradecido. Admiramos a Alcínoo y todos lo amamos porque condujo a su patria al suplicante. Yo también te suplico. Salva a esta huérfana cautiva, pues si no puedo vivir como noble, elegiré una muerte libre. ${ }^{49}$

El conocimiento de los procedimientos y técnicas retóricos es evidente en estas palabras, en las que, para comenzar, se busca la benevolencia del destinatario de la petición con el claro elogio de su persona, al adornarle con los valores que la novela publicita como modélicos, la cultura y educación griega. Seguidamente, se mencionan los delitos cometidos por los piratas, que un personaje de alta alcurnia como Dionisio no puede imitar y que funcionan, por tanto, como argumentos disuasorios. A continuación, se citan dos beneficios que obtendrá al concederle su deseo: el material, la devolución del precio que había pagado por ella, y el espiritual, la equiparación con Alcínoo, el magnánimo rey de los feacios que llevó al errante Odiseo de regreso a su patria. Calírroe muestra con esta mención su cultura literaria, citando al personaje homérico considerado como exemplum de comportamiento ético para con los xénoi, al que espera que Dionisio imite respecto a su persona. Por último, elabora un final lleno de páthos, uno de los recursos más efectivos para mover el ánimo de la audiencia, al insistir en la idea de indefensión de una muchacha privada de su padre y al sugerir el suicidio que solo Dionisio puede impedir, argumento que, por un lado, eleva el poder de su figura y, por otro, deja bien a las claras

${ }^{48}$ Cf. Kaimio, pp. 124-125.

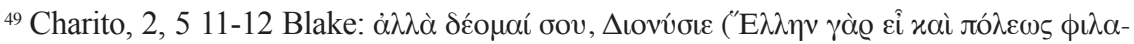

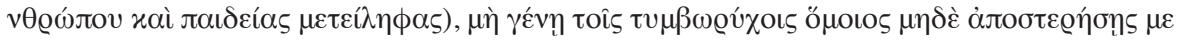

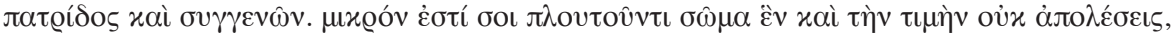

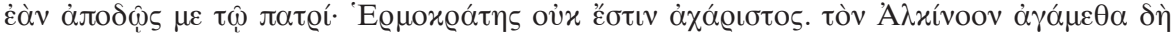

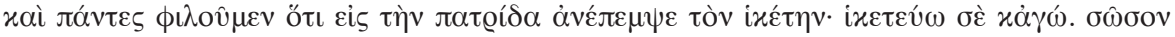

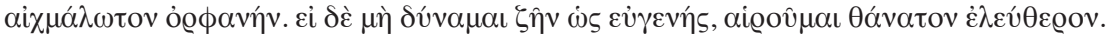


la responsabilidad que pesaría sobre él en caso de negarse a su petición. Calírroe logra, mezclando ficción y realidad, como en los ejercicios retóricos, un discurso verosímil y eficaz que convence al auditorio: Dionisio promete al instante devolverla a Siracusa..$^{50}$

La tercera vez que Calírroe finge a sabiendas y elabora un discurso falso es en la corte del Gran Rey, a la que ha acudido en compañía de su marido Dionisio para asistir a un juicio. El monarca, como todos los personajes masculinos de alto rango que aparecen en la novela, se enamora de la muchacha y envía como mediador para conseguir sus favores a un eunuco de confianza, Artaxates. Éste cree que se le confía una misión banal, porque, como bárbaro que era $(6,5,10)$, tenía la seguridad de que todos se plegarían sin reticencia alguna a los deseos del Gran Rey, e incluso a los suyos propios. Mediante este personaje se escenifica en la novela de Caritón la confrontación entre el griego y el bárbaro, un tópico de amplia tradición literaria, que, sin embargo, respondía a una situación pasada, que había sido radicalmente alterada por la dominación romana sobre todo el mundo conocido. En la novela, este tópico se mantiene ocasionalmente, por un lado, como reflejo del prestigio de la tradición y, por otro, como caracterización adecuada al mundo clásico en el que la trama se sitúa. ${ }^{51}$

El eunuco le plantea a Calírroe la relación amorosa que el Rey le requiere como un beneficio, una muestra de la protección que los dioses le dispensan. Sin embargo, para ella constituye una amenaza al ideal de fidelidad que es característico de la novela y adopta al instante una estrategia defensiva similar a la que usó con Teón: fingiendo no haber comprendido la proposición que acababa de oír, ofrece de ella una interpretación que elude todo aspecto moralmente reprochable, a la vez que permite una digna retirada del eunuco y le evita a ella, que se encuentra bajo la protección de la reina, la necesidad de dar respuesta a la petición $(6,5,6)$ : "Que los dioses le sean siempre favorables al Rey, y él a ti, porque os compadecéis de una mujer infortunada. Yo solo pido que me libere pronto de mi an-

${ }^{50}$ Sin embargo, llevado por una pasión incontenible, la retiene unos días en Mileto. Entre tanto, Calírroe se dará cuenta de que está embarazada de Quéreas y aceptará una boda con él, para evitar que su hijo sea considerado descendiente de los piratas que la habían raptado $(2,9,3)$ y naciera esclavo $(2,11,5)$.

${ }^{51}$ Cf. Bowie, 1991, pp. 188-195, para el análisis de la dicotomía griego-bárbaro en esta novela y en las de Jenofonte de Éfeso y Aquiles Tacio. Por otro lado, Stephens, 2008, analiza el significado de griego y no griego en las novelas antiguas, tanto griegas, como latinas. 
gustia, pronunciando la sentencia, para no ser ya más una molestia para la reina". ${ }^{52}$ Sin embargo, como Artaxates insiste, Calírroe se defiende con argumentos nuevos y más audaces, si bien manteniéndose en la misma estrategia $(6,5,9-10)$ :

No estoy tan loca - dijo- como para considerarme digna del Gran Rey. Yo soy igual a las criadas de las mujeres persas. Y tú, te lo suplico, no evoques mi recuerdo ante tu amo, pues si en el momento no se irrita, después se enfadará contigo, pensando que quieres entregar al señor de toda la tierra a una esclava de Dionisio. Me admiro de que siendo tan inteligente no te des cuenta de la amabilidad del Rey, de que no ama a esta mujer infortunada, sino que la compadece. Dejemos por tanto de hablar, no sea que alguien nos calumnie ante la reina..$^{53}$

En primer lugar, Calírroe resta valor a su persona como posible objeto de atención del Gran Rey, mencionando veladamente el vínculo matrimonial que le une a Dionisio; además, finge creer que tal interés se debe exclusivamente a la actuación del eunuco, que es quien incita al Rey a buscarla,${ }^{54}$ de manera que el monarca queda exento de responsabilidad y Artaxates, como único responsable. Como tal, es él quien recibe la velada amenaza que supone el que llegue a oídos de la reina la proposición que se le hace. El eunuco, receptivo a las palabras de Calírroe, oculta al Rey

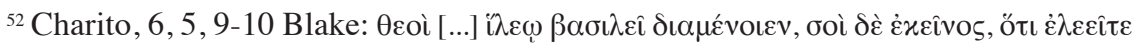

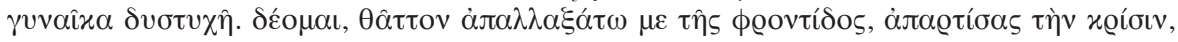

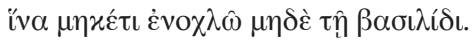

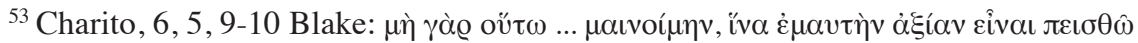

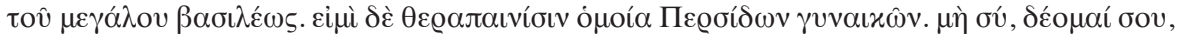
$\mu v \eta \mu \mathrm{ov \varepsilon v́ \sigma \eta ฺ}$

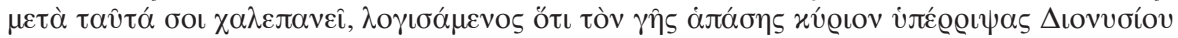

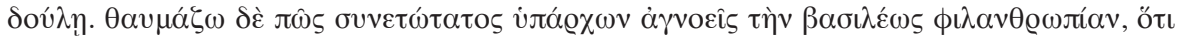

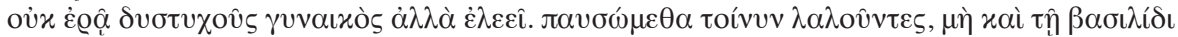
$\tau \iota \varsigma \dot{\eta} \mu \hat{\alpha} \varsigma \delta\llcorner\alpha \beta \alpha \lambda \varepsilon \hat{\imath}$.

${ }^{54}$ Es fácil para Calírroe mantener esta ficción porque desde las primeras palabras que le dirigió por este tema $(6,5,1)$ el eunuco señaló que le estaba haciendo un favor, por el que le debería agradecimiento, y se limitó a decir que el Rey la había visto con agrado, pero que era él quien la recordaba y la alababa para mantener su recuerdo, actuación que el novelista glosa con las palabras siguientes $(6,5,5$ ss. Blake): "Esto lo añadió por su cuenta, pues todo esclavo, cuando habla de su amo a alguien, acostumbra a asociarse

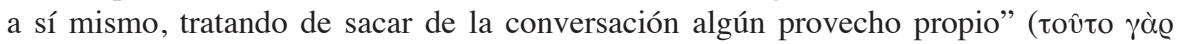

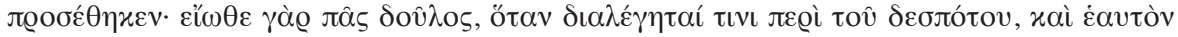

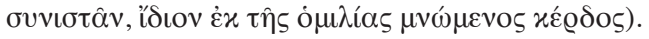


el fracaso de su mediación con ella e incluso intenta, sin lograrlo $(6,7,1)$, que éste desista de su intención de poseerla. Como no lo consigue, recurre a la amenaza explícita, tanto para la persona de Calírroe $(6,7,7)$, como para la de Quéreas $(6,7,11)$, y es entonces cuando la muchacha deja de lado su imagen sumisa y manifiesta una resistencia abierta y una disposición clara a afrontar el sufrimiento que de ella se derive $(6,7,8),{ }^{55}$ produciendo en la trama una situación sin salida ${ }^{56}$ que el novelista resuelve, como en el teatro, con un procedimiento cercano al deus ex machina: una guerra que obliga al Rey a olvidar sus devaneos amorosos.

Como acabamos de ver, los falsos discursos de Calírroe tienen en común, por un lado, que se pronuncian en un marco de amenaza a su persona o sus convicciones, el cual se sitúa siempre en el espacio desprotegido del viaje,$^{57} \mathrm{y}$, por otro, que son utilizados por ella como instrumentos defensivos con los que trata de evitar los daños que la situación amenazante le causaría. Cuando los pronuncia, manifiesta siempre una correcta apreciación de la realidad, un absoluto dominio de la situación y de sí misma, y un indudable conocimiento de los recursos retóricos al uso.

La novela de Caritón, la primera que nosotros conservamos completa, pero también una de las primeras del género, establece un patrón característico para los discursos femeninos de personajes protagonistas que es imitado en obras posteriores como la de Heliodoro.

La trama de la novela de Heliodoro está organizada en torno al engaño urdido por la reina de los Etíopes, Persina, respecto a su hija, Cariclea, la protagonista femenina de la novela. Según la narración de Heliodoro $\left(10,13,2^{58}\right)$, cuando Cariclea fue concebida, Persina estaba mirando un cuadro en el que

${ }^{55}$ Sobre la fortaleza que generalmente muestran las heroínas de las novelas frente a las difíciles situaciones en que se encuentran y la concomitancia de esta fortaleza con la de las vírgenes cristianas de la misma época, cf. Shaw, 1996, y Perkins, 2001.

${ }^{56}$ Nunca se produce en las novelas la muerte de un o una protagonista.

${ }^{57}$ Calírroe sufre ataques físicos también dentro del ámbito de su ciudad de origen, como lo demuestra la patada con la que su marido Quéreas la deja inconsciente en su propia casa. Sin embargo, ninguna heroína de la novela o personaje asimilable a ellas (como Mélite, cf. $2,2,3$ ) reacciona ante los peligros "domésticos" provenientes de sus maridos o sus parejas de enamorados. La doble moral es clara y el desafío al mundo masculino solo se considera heroico cuando se manifiesta para salvaguardar su matrimonio, presente o futuro.

${ }^{58}$ El engaño de Persina no sale completamente a la luz hasta el libro último, porque la novela está estructurada como la Odisea, con un comienzo in medias res a partir del cual se van desvelando los sucesos anteriores y posteriores. 
se representaba a Andrómeda en el momento en que iba a ser rescatada por Perseo, de manera que su hija nació, como este personaje mitológico, de piel blanca, en lugar de negra, como sus progenitores ${ }^{59}$ Como Persina teme que el rey, creyéndola infiel, ${ }^{60}$ cause la muerte de su hija y la suya propia, decide anunciar que ha nacido muerta y sacarla del palacio, junto con unas prendas de reconocimiento (gnorísmata) y una carta en la que cuenta sus orígenes y la causa de su abandono. La niña es llevada a Delfos por un sacerdote griego, Caricles, quien la cría como hija suya, en el ambiente de religiosidad propio de ese santuario. Lo novedoso de la novela de Heliodoro respecto a las demás consiste en que el viaje que contiene no es de ida y vuelta, como el de las demás novelas, sino el de regreso de Cariclea a su país de origen, Etiopía. Y es durante ese viaje que Cariclea utiliza en diversas ocasiones el discurso falso, siguiendo la pauta marcada por Calírroe.

En uno de los numerosos episodios de ese viaje, Cariclea y su pareja, Teágenes, caen en manos de Tíamis, un antiguo sacerdote de Isis que, expulsado de su ciudad por haber cometido una falta, se ha convertido en el jefe de un ejército de bandidos. Enamorado a primera vista de su prisionera, e impresionado por el porte real que emana de ella, decide tomarla no ya como esclava, sino como esposa, y tiene la deferencia de pedirle, ante los hombres que conforman su ejército, $\mathrm{y}$, por tanto, en público, que acceda a casarse con él. Cariclea le responde con una magnífica muestra de discurso falso, que se organiza en torno a los siguientes pasos argumentativos (1,21,3 ss.):

a) Comienza diciendo que ella, como mujer que es, debería callar, y que lo decoroso sería que su hermano tomara la palabra. Miente ya desde este mismo comienzo respecto a su relación con Teágenes, debido a que, en la situación descrita, se encontraría en un peligro inminente siendo su pareja, pero no siendo su hermano, en cuyo caso la legislación de la época le asignaba el papel de kýrios, y, por tanto, era él quien debía decidir sobre su matrimonio. De ahí que explique que ella debería callar y su hermano tomar la palabra. Continúa dando las gracias porque se le permita utilizar la palabra, y convierte este uso anómalo que ella se ha adjudicado sin pedir a nadie consentimiento en una prueba de generosidad de los varo-

${ }^{59}$ Este dato, tan sorprendente para nuestra mentalidad, indica, en el mundo novelesco, la influencia de algún poder sobrenatural que actúa desde la misma concepción de la muchacha, la existencia de un poder que la acompañará a lo largo de toda su historia. Cf. Suárez de la Torre, 2004.

${ }^{60}$ Sobre la gravedad del delito de adulterio, cf. Calero Secall, 2006. 
nes presentes, resaltando especialmente la elogiosa actitud de Tíamis, que busca conseguir una cosa justa (el tener relaciones con una esclava de su propiedad) mediante la persuasión y no mediante la violencia. Son, precisamente, estas virtudes las que la han llevado a salirse de su hábitos - se refiere, de nuevo, al silencio que debería observar- y de los propios de una doncella - afirmando, de este modo, que lo es -, para responder al vencedor acerca de su matrimonio, que se le ha solicitado también en una situación inusual, en público, lo que le obliga a hacer también un discurso público, situación absolutamente inhabitual para una mujer, pero que ella resuelve con soltura.

b) Tras haber justificado el ser ella quien posee la palabra, Cariclea, como suele ser habitual entre desconocidos, se presenta a sí misma y a su hermano y da cuenta de las circunstancias que les han llevado a la situación en la que se encuentran. Compone, como ya hiciera Calírroe, un relato en el que se mezclan hechos reales y falsos, pero conformando un conjunto verosímil: dice que son jonios (falso), que proceden de una familia principal de Éfeso (falso) y que ella es sacerdotisa de Ártemis (verdad) y su hermano de Apolo (verdad). Que se dirigían a Delos (falso), cuando se cumplió el turno anual de su sacerdocio, pero que una tormenta (falso) les hizo zozobrar hasta encallar en el lugar en el que fueron encontrados por unos bandidos (falso) que asesinaron a todos sus compañeros. ${ }^{61}$ En esta penosa situación fueron encontrados por Tíamis y su banda, el único hecho beneficioso que les ha sucedido en medio de tanta desgracia (falso: es el elogio de lo irremediable, que sirve de eficaz captatio benevolentiae), ya que les permitió cambiar el temor que antes sentían, por la situación en la que ahora se encuentran: siendo capaces de decidir acerca de su matrimonio. Un matrimonio que ella accede a celebrar (falso), porque honrar a una cautiva con el lecho del vencedor es gran dicha (lugar común, que encaja con la situación), y porque el hecho de que ella, muchacha consagrada, sea legítima esposa del hijo de un sacerdote, que dentro de poco será también sacerdote, es prueba de la tutela divina de la que goza.

${ }^{61}$ Como Crespo (1979, p. 99, n. 43) señala, la condición de sacerdote implica ser de alto linaje (cf. D. 57, 46), por lo que el relato muestra en este punto una absoluta coherencia. También es perfectamente creíble la aparición de Éfeso (y Ártemis), que ya se encuentra en otras novelas, y la de Delos, santuario que gozaba de una gran fama en el s. $\mathrm{v}$, como sede de la liga marítima ática. 
c) Una vez captada con esta aceptación del matrimonio la voluntad no solo de Tíamis, sino la de toda su banda, hace una petición relacionada con la condición de sacerdotes de ambos, a la que el jefe de los bandidos no se puede negar: que aplace la boda hasta que lleguen a Menfis, que sería el lugar sagrado más adecuado para su unión.

La actuación de Cariclea es tan convincente, sus palabas son tan verosímiles, que hasta el propio Teágenes $(1,25,1)$ le cree y piensa que han quedado rotos los juramentos que les unían mutuamente. Y entonces ella debe explicarle que ha dicho lo oportuno para conseguir salvarle la vida a él $(1,26,2)$ y ganar, con este consentimiento aparentemente, un aplazamiento que puede traer la salvación a ambos, siempre que los dos sean capaces de mantener el engaño urdido como un arma secreta $(1,26,5)$. Cariclea termina esta justificación ante su amado con unas palabras que dejan claras las intenciones que la mueven $(1,26,6)$ : "bella es también a veces la mentira, cuando aprovecha a quien la dice sin dañar en nada a quien la oye", ${ }^{62}$ y que explican el uso repetido que del discurso falso hace en otras ocasiones en las que también se encuentra en peligro. ${ }^{63}$

Aunque Cariclea no se encuentra, como Calírroe, sola en sus aventuras, sino que la acompañan figuras masculinas protectoras, como el propio Teágenes o el sacerdote Tíamis, ella es, como la heroína de Caritón, perfectamente capaz de comprender con precisión el peligro que la acecha y de diseñar el plan que pueda evadirlo, sirviéndose con inteligencia y decisión del discurso falso, construido conforme a las ideas y los procedimientos de persuasión que se enseñaban en las escuelas retóricas. ${ }^{64}$

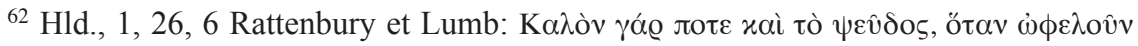

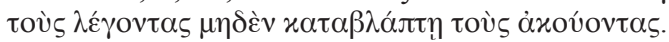

${ }^{63}$ Cuando son capturados $(5,8,2)$ por Mitranes, jefe de la guardia de Oroóndates, el sátrapa del Gran Rey en Egipto, situación en la que, por idea de Nausicles, Cariclea se hace pasar por otra persona (Tisbe); o cuando caen en manos del pirata Traquino, que persigue a Cariclea desde que salieron de Zacinto $(5,24,2)$; o cuando Ársace, la esposa del sátrapa persa, trata de que Teágenes responda a sus deseos amorosos (7, 11, 7 ss.) o, incluso, cuando, ya en Méroe, y en presencia de Persina e Hidaspes, Cariclea y Teágenes se hacen pasar en los primeros momentos por hermanos, hasta que la situación les obliga a confesar la verdad $(10,18,2)$.

64 Explicar la capacidad de convicción de Cariclea es el objeto del artículo de L. Pernot, 1992, quien repara en la excelente educación que la joven recibió en Delfos, como medio de hacer verosímil su dominio de las técnicas retóricas, pero que concluye que el dibujo del personaje, tan hábil para convencer como una sirena, fue elección del autor, que buscaba, con ésta y otras características que hemos mencionado (su nacimiento, el color de su piel), construir un claro objeto de admiración y sorpresa para el lector. 
El discurso falso no es solo propio de las protagonistas de la novela, sino que aparece también en un personaje secundario, como Mélite, de la novela de Aquiles Tacio. El novelista hace un retrato muy positivo de esta mujer que, rica y educada a la manera griega, aparece en la trama cuando, creyéndose viuda, se enamora del protagonista, Clitofonte, quien, a su vez, cree también que su amada, Leucipa, ha muerto. El joven conoce a la supuesta viuda en Egipto y, aunque reticente a consumar su amor, la acompaña en su viaje de regreso a su Éfeso natal, donde súbitamente reaparece su marido, Tersandro, a quien se había dado por desaparecido en un viaje. Tersandro, personaje amoral y violento, descarga su cólera contra Clitofonte, creyéndole el amante de su mujer. El discurso falso que Mélite pronuncia se diferencia del de las protagonistas de las novelas en que va dirigido a su propio marido y no a pretendientes externos al matrimonio o a la pareja de enamorados. Sin embargo, tiene la misma intención defensiva, ya que busca aplacar la cólera de Tersandro, de modo que su violencia no caiga sobre ella y sobre Clitofonte. Mélite comienza (6, 9, 1 ss.) justamente negando que Clitofonte sea su amante (verdad) y pasa a explicar los motivos por los que se encuentra en su casa, pidiéndole que los considere como un juez imparcial que se deja conducir solo con la razón.

Su estrategia defensiva se basa en la ingeniosa y audaz idea de establecer un paralelismo entre Clitofonte y Tersandro, buscando que éste se identifique emocionalmente con el primero. Cuenta que Clitofonte es fenicio y de alta alcurnia (verdadero) y que tuvo, como el mismo Tersandro, una navegación infortunada en la que perdió su mercancía (parcialmente verdadero) y que ella, al oír su historia, se acordó de su marido (falso), y, sospechando que podía haber tenido un percance similar en el mar, en memoria suya, acogió a Clitofonte en su casa y lo salvó (falso), como a otros muchos, víctimas también de naufragios (falso). Esta versión, que omite totalmente la relación amorosa que Mélite había buscando en Clitofonte desde que lo conoció, se refuerza contando que la amada de Clitofonte es Leucipa (verdad), de la que se vio separado anteriormente, pero a la que había reencontrado precisamente en su finca (verdad); recordando los años de matrimonio en que Tersandro no ha tenido ocasión de hacerle reproche alguno $(6,10,2)$ y elaborando una refutación de gusto sofístico contra Rumor y Calumnia, como fuentes inseguras de conocimiento. Mélite, que tampoco descuida la fuerza persuasiva del páthos, acompaña sus palabras con gestos amorosos, con los que logra convencer, aunque solo sea temporalmente, a Tersandro $(6,11,1)$ : “Al tiempo que le hablaba le 
tomó la mano y quiso besarlo. Y a él, que estaba más aplacado, lo conmovía la verosimilitud de lo que Mélite contara [...]"). ${ }^{65}$

Aunque se trata de un discurso pronunciado en el ámbito privado, Mélite adopta estrategias propias de los discursos forenses, ya que Tersandro, en tanto que esposo suyo, es su kýrios, y tiene, por tanto, como un juez, la posibilidad de castigarla. El discurso sigue, efectivamente, la preceptiva habitual, con la petición de imparcialidad en el comienzo, la narración central de lo sucedido, la refutación del argumento contrario, representada aquí en el ataque a Rumor y Calumnia, y el final que busca conquistar el lado afectivo del "juez" Tersandro. Mélite miente, por tanto, valiéndose, de sólidos conocimientos de retórica, como las heroínas protagonistas, muestra el mismo aplomo que ellas y coincide con ellas en su intención última, ya que lo esencial de su discurso es demostrar que se ha mantenido fiel a su matrimonio, incluso cuando se creía viuda.

Junto a los discursos defensivos que hemos analizado hasta ahora, se encuentra en la novela algún discurso falso cuyo objetivo es ofensivo, que busca la ruina de su destinatario, debido, como era común en la tragedia clásica, a un afán de venganza. Estos discursos aparecen en la novela ligados a historias que contienen elementos presentes en el "motivo de Putifar", que también se encuentra presente en las tragedias griegas. ${ }^{66}$

Uno de ellos aparece en la novela de Jenofonte de Éfeso. El protagonista masculino de esta novela es Habrócomes, quien, tras su matrimonio con Antia, emprende un viaje a Egipto. Pero su embarcación cae en manos de unos piratas, que los conducen a Tiro, donde la hija del jefe de la banda agresora, Manto, se enamora de él. Manto no pertenece, como Mélite, a las clases sociales más elevadas, ni ha sido educada en la paideía griega, sino que es descrita como una bárbara que alberga en su pecho un sentimiento amoroso sobre el que no tiene control $(2,2,2$ y 2, 2, 5). Dominada por él, escribe una carta a Habrócomes en la que le conmina a aceptar su amor o a sufrir penosas consecuencias para sí mismo, para Antia y para los amigos que con ellos habían sobrevivido $(2,5,1)$. Como obtiene una respuesta negativa, se venga acusándolo ante su padre de haberla agredido: ${ }^{67}$

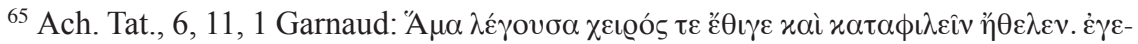

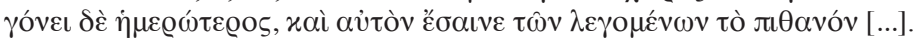

${ }^{66}$ Cf. Lucas de Dios, 1992.

${ }^{67}$ Las traducciones de Jenofonte las tomamos de J. Mendoza, 1979. 
Compadécete, padre, de tu hija injuriada por un esclavo. Pues el casto Habrócomes intentó quitarme la virginidad y conspiró incluso contra mí diciendo que me amaba. Toma tú digna venganza de él por tal atrevimiento, o, si vas a entregar a tu hija a los esclavos, me mataré a mí misma para evitarlo de antemano. ${ }^{68}$

Es éste un discurso sin artificio retórico alguno, ya que consta únicamente de la apelación a la compasión de su padre, de la escueta exposición de la causa por la que se le debe compadecer y de la consecuencia patética que resultaría de no hacerlo. Todo en él es falso, pero logra su objetivo de venganza y causa terribles sufrimientos a la pareja de protagonistas.

En la novela de Heliodoro se encuentra también un episodio relacionado con el "motivo de Putifar", aunque no se ven implicados en él los protagonistas de la novela, sino un personaje secundario, Cnemón, que los acompaña en algunas de sus aventuras. La acción transcurre en Atenas y está protagonizada por Deméneta, una mujer griega, pero que comparte con Manto el retrato moralmente negativo que hace de ella el novelista: es habilísima en enloquecer a cualquier hombre mediante engaños $(1,9,2)$. Casada con un hombre de edad, se enamora de su hijastro, Cnemón, y le prodiga manifestaciones de amor apasionadas y carentes de pudor $(1,9,3)$. Cuando es rechazada, busca su perdición, acusándole, primero, de agredirla físicamente por medio de un discurso de tono familiar sin artificio retórico ninguno $(1,10,4) \mathrm{y}$, representando, luego, una escena falsa por medio de la cual convence a su padre de que su hijo trata de asesinarlo $(1,12,2)$. Cnemón es acusado de asesinato y condenado al destierro.

Por último, cabe mencionar al personaje Cino, de la novela de Jenofonte de Éfeso, en la que aparece como la esposa de un anciano soldado al que Habrócomes es vendido en Egipto. Se relaciona este episodio con el "motivo de Putifar" porque el muchacho es tratado como un hijo por su amo y porque su esposa, descrita como mujer repugnante y con una desvergüenza sin límites $(3,12,3)$, se enamora del muchacho y le propone matar a su marido para casarse con él. Ella consuma el crimen, pero Habrócomes se niega a unirse con ella y la abandona. Defraudada, Cino acusa a Habrócomes de la muerte de su marido, y él es detenido y condenado. Este personaje es, de entre los

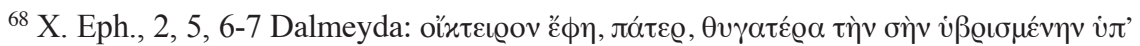

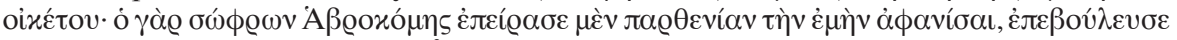

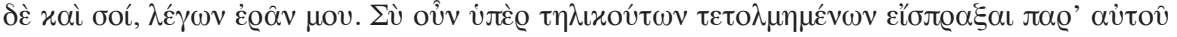

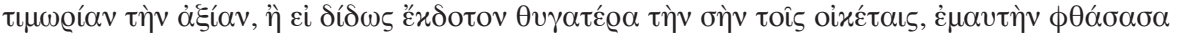

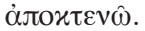


tres relacionados con el episodio de Putifar, el que pertenece a la clase social más baja y sus palabras ni siquiera son consignadas por el novelista.

Manto, Deméneta y Cino tienen en común el ser personajes secundarios, el no pertenecer a las clases altas de la sociedad, el no recibir una caracterización elogiosa por parte de los novelistas y el sentir una pasión amorosa que no pueden controlar y que pretenden imponer a sus enamorados. Este tipo de amor representa la antítesis del que se propone como modélico en la novela, en la que el sentimiento amoroso se encauza en un matrimonio basado en el amor entre iguales mutuamente enamorados y que se guardan mutua fidelidad. Por ello, frente al happy end característico de las novelas para todas sus protagonistas femeninas, que regresan sanas, salvas y junto a sus amados a sus hogares, Manto, Deméneta y Cino, las antiheroínas de la novela, resultan siempre defraudadas en sus expectativas amorosas, y en las consecuencias de su venganza, que se vuelve contra ellas como un bumerán, causándoles graves daños: Manto debe soportar que su marido, Meris, se enamore también de Antia, la esposa de su deseado Habrócomes (2, 11, 1 ss.), y Deméneta $(1,17,5)$ y Cino (4, 4,2 ) acaban perdiendo la vida como consecuencia de su falsa acusación.

\section{Conclusiones}

La novela, en tanto que tiene aspiraciones educativas y propone como modélico un comportamiento amoroso determinado, ofreciendo un paradigma de organización del núcleo de la estructuración política y social de la comunidad, el ốkos, se alinea, en el conjunto de la literatura griega, junto con los géneros serios, como la épica o la tragedia. ${ }^{69}$ Los protagonistas de las novelas se convierten en héroes y heroínas al encarnar las pautas que se proponen como dignas de imitar, constituyéndose, de este modo, en modelos éticos.

Este hecho condiciona las características de los discursos falsos puestos en boca de las protagonistas femeninas. Efectivamente, estos discursos son siempre defensivos, y son instrumentos que se utilizan al servicio del ideario amoroso que se expone como modélico: la defensa de un matrimonio fundado en el amor mutuo y fiel de una pareja de jóvenes, los cuales invariablemente pertenecen a las clases altas y helenizadas de las

${ }^{69}$ La voluntad pedagógica de la novela ha sido apreciada prácticamente por la totalidad de los comentaristas modernos. Una de su más recientes expresiones se encuentra en Brioso, 2009, pp. 175-183. 
ciudades.$^{70}$ Además, estos discursos están siempre en boca de las protagonistas femeninas de más elevado nivel social (Calírroe y Cariclea), es decir, de las pertenecientes al medio en el que se tenía acceso a los grados más altos de educación. Los novelistas dibujan a estos personajes como mujeres inteligentes, capaces de valorar adecuadamente la situación de peligro en que se encuentran en el territorio desprotegido del viaje y de enfrentarse a ella con la fuerza que aporta el sostenimiento de un ideal, dueñas de sí mismas y de los recursos retóricos que les permiten manejarla. ${ }^{71}$

Características semejantes tiene también un personaje femenino secundario, Mélite, que comparte con Calírroe y Cariclea el elevado rango social, la educación a la griega y su dominio de la retórica. Su discurso tiene también una finalidad defensiva y es acorde con el ideario de la novela, pero en una dirección distinta: su objetivo no es, como el de las protagonistas, evitar relaciones fuera del matrimonio, sino demostrar que ella no ha cometido adulterio.

Este tipo de discurso falso e inocuo que se pronunciaba a favor de la institución matrimonial contaba con el prestigioso precedente de Penélope, el paradigma de la mujer fiel dentro de la literatura épica, o de la $\mathrm{He}$ lena de Eurípides, dentro de tradición trágica. Particularmente este último personaje se encuentra en una situación muy similar a la de las heroínas griegas - fuera de su patria, pretendida por un hombre poderoso y deseosa de mantenerse fiel a su esposo - y resuelve la situación con armas similares - la astucia y el buen uso de la palabra-, si bien los contextos históricos y culturales y el objetivo que el autor pretende con su obra son evidentemente diferentes. ${ }^{72}$

${ }^{70}$ Estas dos características han hecho suponer a Lalanne (2006, pp. 277-279) que la novela, que estaba dirigida como el resto de la literatura culta de la época a las clases más elevadas de la sociedad, proponía a dichos grupos este tipo de comportamiento erótico como un medio de mantener el poder y la situación social privilegiada de la que disfrutaban, evitando de este modo que personas pertenecientes a otro medio social o a otro medio cultural emparentaran con ellos.

${ }^{71}$ Es significativo a este respecto que Cloe, la protagonista pastora de la novela de Longo, apenas tiene discursos directos en la novela, y ello está, sin duda, relacionado con la ambientación de la trama en un ámbito rústico, alejado de la cultura y la educación que se desarrollaban en el marco urbano, y con la ausencia de viaje. A lo largo de la obra, y a medida que su relación amorosa se consolida, Cloe va perdiendo presencia en la obra y voz, para sumirse en el final en el silencio también característico del discurso femenino; cf. Lalanne, 2006, pp. 136-145.

${ }^{72}$ Concretamente para la obra de Eurípides, cf. Redondo Moyano, 2010. 
Por otro lado, el modelo trágico de Hécuba o de Clitemnestra, es decir, el discurso falso surgido de una voluntad de venganza personal y que busca un daño para la persona contra la que se dice, se encuentra también en la novela, pero solo en personajes secundarios, que no son, como las protagonistas, modelos de comportamiento, sino que representan el papel del antihéroe. Efectivamente estos personajes experimentan pasiones amorosas que les dominan y los objetos de su amor están fuera de la institución del matrimonio, ya sea porque ellas están casadas, ya sea porque su enamorado lo esté, de manera que los novelistas nunca les refrendan con el éxito que acompaña a las protagonistas. Su caracterización es coherente con este rol: nunca pertenecen a las clases elevadas de la sociedad y no son griegas o no han recibido educación griega, de manera que sus discursos directos no son artísticos, sino que pertenecen al nivel del habla cotidiana y solo en contadas ocasiones merecen ser reproducidos en la trama.

\section{BIBLIOGRAFÍA}

\section{Fuentes}

Achille Tatius D’AleXandrie, Le Roman de Leucippé et Clitophon, texte établi et traduit par Jean-Philippe Garnaud, Paris, Les Belles Lettres, 1991 (Collection des Universités de France, Budé).

CARItón de Afrodisias, Quéreas y Calírroe. JeNOFONTE de ÉFESo. Efesíacas. Fragmentos novelescos, traducción de J. Mendoza, Madrid, Gredos, 1979.

CHARITONIS APHRODISIENsIs, De Chaerea et Calirhoe amatorium narrationum, W. E. Blake (ed.), Oxford, Carendon Press, 1938.

Ejercicios de retórica (Teón, Hermógenes, Aftonio), traducción de M. D. Reche Martínez, Madrid, Gredos, 1991.

EuRíPIDES, Iphigenia in Tauris, M. J. Cropp (ed.), Warminster, Aris \& Phillips, 2000. EURIPIDES, Orestes, ed. with transl. and commentary by M. L. West, Warminster, Aris \& Phillips 1987.

HÉLIOdORE, Les Éthiopiques, texte établi par R. M. Rattenbury et T. W. Lumb, et traduit par J. Maillon, Paris, Les Belles Lettres, 1935 (Collection des Universités de France, Budé).

Heliodoro, Las Etiópicas o Teágenes y Cariclea, traducción de E. Crespo Güemes, Madrid, Gredos 1979.

Longo, Dafnis y Cloe; Aquiles Tacio, Leucipa y Clitofonte; YÁmblico, Babiloníacas, introducciones, traducciones y notas de M. Brioso Sánchez y E. Crespo Güemes, Madrid, Gredos, 1997.

NAUCK, A. (ed.), Tragicorum Graecorum Fragmenta reconsuit Augustus Nauck. Supplementum continens nova fragmenta Euripidea et Adespota apud scriptores veteres reperta, adiecit Bruno Snell, Hildesheim, 1964. 
RADT, S. (ed.), Tragicorum Graecorum Fragmenta, vol IV: Sophocles, Göttingen, Vandenhoeck \& Ruprecht, 1977.

WeSt, M. L. (ed.), Iambi et elegi graeci: Ante Alexandrum Cantati, vol. 2: Callinus, Mimnermus, Semonides, Solon, Tyrtaeus, Oxford, Clarendon Press, 1992.

XENOPHON D'Ephèse, Les Ephésiaques ou le roman d'Habromès et d'Anthia, texte établi par G. Dalmeyda, Paris, Les Belles Lettres, 1926 (Collection des Universités de France, Budé).

\section{Estudios}

Blanchard, Alain, “Destins de Ménandre”, Ktema, 22, 1997, pp. 213-225.

BowIE, Ewen, "Hellenes and Hellenism in Writers of the Early Second Sophistic", en S. Said, Hellenismos: quelques jalons pour une histoire de l'identité grecque, Leiden / New York, E. J. Brill, 1991, pp. 183-204.

BowIE, Ewen, "The Chronology of the Earlier Greek Novels since B. E. Perry: Revisions and Precisions", Ancient Narrative, 2, 2002, pp. 47-63.

_, "Literary milieux", The Cambridge Companion to the Greek Roman Novel, Cambridge, Cambridge University Press, 2008, pp. 17-38.

BRIOSO SÁNCHEZ, Máximo, “Autor, narrador, lector y narratio en la novela griega antigua”, en E. A. Ramos Jurado, Cuatro estudios sobre exégesis mítica, mitografía y novela griegas, Zaragoza, Libros Pórtico, 2009, pp. 153-248.

CALERO SECALl, Inés, "Los delitos de adulterio y rapto en la ficción de la novela griega”, Minerva, 19, 2006, pp. 63-83.

Caragounis, Chrys C., "Atticism. Agenda and Achievement", en Ch. C. Caragounis, (ed.), Greek. A Language in Evolution, Hidesheim / Zürich / New York, Georg Olms Verlag, 2010, pp. 153-176.

CRIBIORE, Raffaella, Writers, Teachers and Students in Graeco-Roman Egypt, Atlanta, Scholars Press, 1996.

_, Gymnastics of the Mind: Greek Education in Hellenistic and Roman Egypt, Princeton, Princeton University Press, 2001.

CRISMANI, Daria, Il teatro nel romanzo ellenistico d'amore e di avventure, Torino, Edizioni dell'Orso, 1997.

Foley, Helene P., Female Acts in Greek Tragedy, Princeton, Princeton University Press, 2001.

Futre Pinheiro, Marília Pulquerio, “A Viagem na Antiguidade: Uma proposta didáctica”, Classica, 20, 1994, pp. 319-341.

_, "The Language of Silence in the Ancient Greek Novel”, en Siegfried Jäkel and Asko Timonen (eds.), The Language of Silence I, Turku, Turun Yliopisto, 2001, pp. 127-140.

Garcia Gual, Carlos, "L' initiation de Daphnis et Chloé”, en A. Moreau (ed.), L'initiation I. Les rites d'adolescence et les mystéres. Actes du Colloque Int. de Montpellier, Montpellier, Université Paul Valéry, 1992, pp. 157-166.

Hallett, Judith P. y Skinner, Marilyn B., Roman Sexualities, Princeton, 1997. 
Hunter, Richard, "Longus, Daphnis and Chloe", en G. Schmeling (ed.), The novel in the Ancient World, second edition, Boston / Leiden, Brill, 2003, pp. 361-386. IMBERT, Claude, “Le roman grec: du protreptique à l'Éducation sentimentale", en Le Monde du Roman Grec, Paris, 1992, pp. 321-338.

KAIMIO, Maarit, "How to Manage in the Male World", Acta Antiqua Hunaricae, 36, 1995, pp. 119-132.

KazazIs, J. N., “Atticism”, en A. F. Christides (ed.), A History of Ancient Greek. From the Beginnings to Late Antiquity, Cambridge: Cambridge University Press, 2007, pp. 1200-1212.

Konstan, David, Sexual Symmetry: Love in the Ancient Novel and Related Genres, Princeton, Princeton University Press, 1994.

Kytzler, Bernhard, "Xenophon of Ephesus", en G. Schmeling (ed.), The novel in the Ancient World, second edition, Boston / Leiden, Brill, 2003, pp. 336-360.

Lalanne, Sophie, Une éducation grecque. Rites de passage et construction des genres dans le roman grec ancien, Paris, Éditions La Découverte, 2006.

LuCAs DE Dios, José María, "El motivo de Putifar en la tragedia griega", Epos, 8, 1992, pp. 37-56.

MARINčič, Marko, “Advertising One's Story. Text and Speech in Achilles Tatius' Leucippe and Clitophon", en V. Rimell (ed.), Seeing Tongues, Hearing Scripts: Orality and Representation in the Ancient Novel, Groningen, Barkhuis \& Groningen University Library, 2007 (Ancient Narrative Suppl. 7), pp. 168-200.

McClure, Laura, Spoken Like a Woman, Princeton, Princeton University Press, 1999.

O' Sullivan, James N., Xenophon of Ephesus, Berlin / New York, W. de Gruyter, 1995. Perkins, Judith, "Space, Place, Voice in the Acts of the Martyrs", en D. R. MacDonald (ed.), Mimesis and Intertextuality in Antiquity and Christianity, Harrisburg, Trinity Press International, 2001,pp. 117-137.

Pernot, Laurent, "Chariclée la Sirène", en M.-F. Baslez, P. Hoffmann y M. Trédé, (eds.), Le Monde du Roman Grec, Paris, Presses de l'Ecole Normale Supérieure, 1992, pp. 43-51.

PiCAZo Gurina, Marina, Alguien se acordará de nosotras, Barcelona, Bellaterra, 2008.

PlePelits, Karl, "Achilles Tatius", en G. Schmeling (ed.), The Novel in the Ancient World, second edition, Boston / Leiden, Brill, 2003, pp. 387-416.

ReArdon, Bryan P., Courants littéraires grecs des II et III siècles après J. C., Paris, Les Belles Lettres, 1971, pp. 309-405.

_, "Chariton", in G. Schmeling (ed.), The Novel in the Ancient World, second edition, Boston / Leiden, Brill, 2003, pp. 309-335.

REDOndo Moyano, Elena, "Aspecto físico y retórica en la novela griega antigua", en J. Alonso Aldama, C. García Román, I. Mamolar Sánchez (eds.): $\Sigma \tau \iota \varsigma$

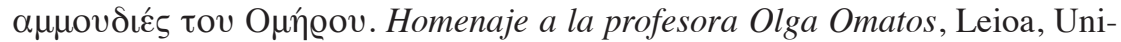
versidad del País Vasco, 2007a, pp. 691-706.

_, "Nicolao de Mura, Progumnásmata", en G. Lopetegui Semperena y M. T. Muñoz García de Iturrospe (eds.), Antología de textos sobre retórica (ss. IV-IX), Bilbao, Universidad del País Vasco, 2007b, pp. 73-148. 
_, "La Helena de Eurípides y los roles de género", en F. de Martino \& C. Morenilla (eds.), Teatro y sociedad en la Antigüedad clásica. La redefinición del rôle de la mujer por el escenario de la guerra, Bari, Levante, 2010, pp. 285-308.

_, "Space and Gender in the Ancient Greek Novel", en Marília P. Futre Pinheiro, Marilyn B. Skinner, Froma I. Zeitlin (eds.), Narrating Desire: Eros, Sex, and Gender in the Ancient Novel, Berlin, De Gruyter, 2012, pp. 29-48.

Ruiz Montero, Consuelo, "The Rise of the Greek Novel", en G. Schmeling (ed.), The Novel in the Ancient World, second edition, Boston / Leiden, Brill, 2003, pp. 48-54.

_, La novela griega, Madrid, Síntesis, 2006.

Soja, Edward W. (ed.), Postmodern Geographies: The Reassertion of Space in Critical Social Theory, London, Verso Press, 1989.

StePhENs, Susan, "Cultural Identity", en The Cambridge Companion to the Greek Roman Novel, Cambridge, Cambridge University Press, 2008, pp. 56-71.

Shaw, Brent D., "Body / Power / Identity: Passions of the Martyrs", Journal of Early Christian Studies, 4, 1996, pp. 269-312.

SuÁREZ DE LA TORRE, Emilio, "La princesa etíope que nació blanca: La mirada y la contemplación en las Etiópicas de Heliodoro", en Cuadernos de Filología Clásica (Griego), 2004 (Estudios griegos e indoeuropeos, 14), pp. 201-233.

WhitMarsh, Tim, "Class", The Cambridge Companion to the Greek and Roman Novel, Cambridge, Cambridge University Press, 2008, pp. 72-87.

WinkLER, John J., "The Education of Chloe: Hidden Injuries of Sex", en The Constraints of Desire: Essays in the Anthropology of Sex and Gender in Ancient Greece, New York / London, Routledge, 1989, pp. 1001-1126. 
